\title{
Effectiveness of the method of soil substitution under the foundations during the construction of a secondary school
}

\author{
Valentina Kurochkina ${ }^{1, *}$, and Irina Yakovleva ${ }^{1}$ \\ ${ }^{1}$ Moscow State University of Civil Engineering, 129337, 26, Yaroslavskoye Shosse, Moscow, Russia
}

\begin{abstract}
The hydro-geological conditions at the secondary school construction site in the village of Putilkovo, Moscow Region, were underestimated, and the method of soil replacement under the foundation plates turned out to be inefficient. A brook in the construction zone and a high level of ground waters led to the wash-out of the soil from under the foundation plates at the time of spring floods. The construction works stopped because of the deformation of soil layers under the foundation plates as well as of the danger of the structure fall. The geodetic observations of the foundation settling and the inspection of bearing capacity of monolith structural elements were carried out, and the measures were taken on the strengthening of foundation soils by the grout injection method with the arrangement of soil-and-cement columns. The monolith basement structures were strengthened as well. The under-estimation of hydro-geological conditions at the design stage led to incorrect design solutions. The construction outage, the development of new design solutions and the introduction of these design solutions led to the increase in the project cost and a longer construction period.
\end{abstract}

\section{Introduction}

The engineering surveying works (in accordance with SP 47.13330.2012 "Engineering surveying works in construction. Basic statements." (Actual edition of SNiP 11-02-96)) for the preparation of design documents are carried out to obtain the initial data for the analysis of foundations and structures. They also precede the design of structural engineering protection, the performance of earth works and the formulation of final design solutions concerning the preparation, expertise, consultation and assertion of design documents. In the process of design and analysis of foundations, the determining factor is the presence of ground or surface waters, which influence the water content in the construction site soils [1, 2].

With the design and construction works on soft grounds (in accordance with SP 45.13330.2012 "Earth structures and foundations." (Actual edition of

\footnotetext{
Corresponding author: kurochkina@mgsu.ru
} 
SNiP 3.02.01-87) and SP 22.13330.2010 "Foundations of buildings and structures." (Actual edition of SNiP 2.02.01-83*)), different methods of soil strengthening are used. Nowadays, the most popular methods of improvement of soils under the foundation plates are the soil replacement method [3-5] and the grout injection method [6-9]. The soft ground under the foundation plate is replaced by the firm ground with a high shear strength. As an artificial soil layer under the foundation, the beds from sand, gravel, crushed stone, slag or various waste products are used (Fig.1). This artificial soil layer contributes much to the leveling of possible non-uniform settlings as well as to the reduction of the foundation contour interval depth.

The sand beds are compacted either layer-by-layer or at once within the full height limits depending on the type of compacting facilities; they usually use here mechanical compactors and rollers, vibrators, etc. The sand in the sand bed should be compacted, as a loose sand layer may give an additional settling. It is prohibited to place frozen sand mass into the sand bed as it resists to the compaction.

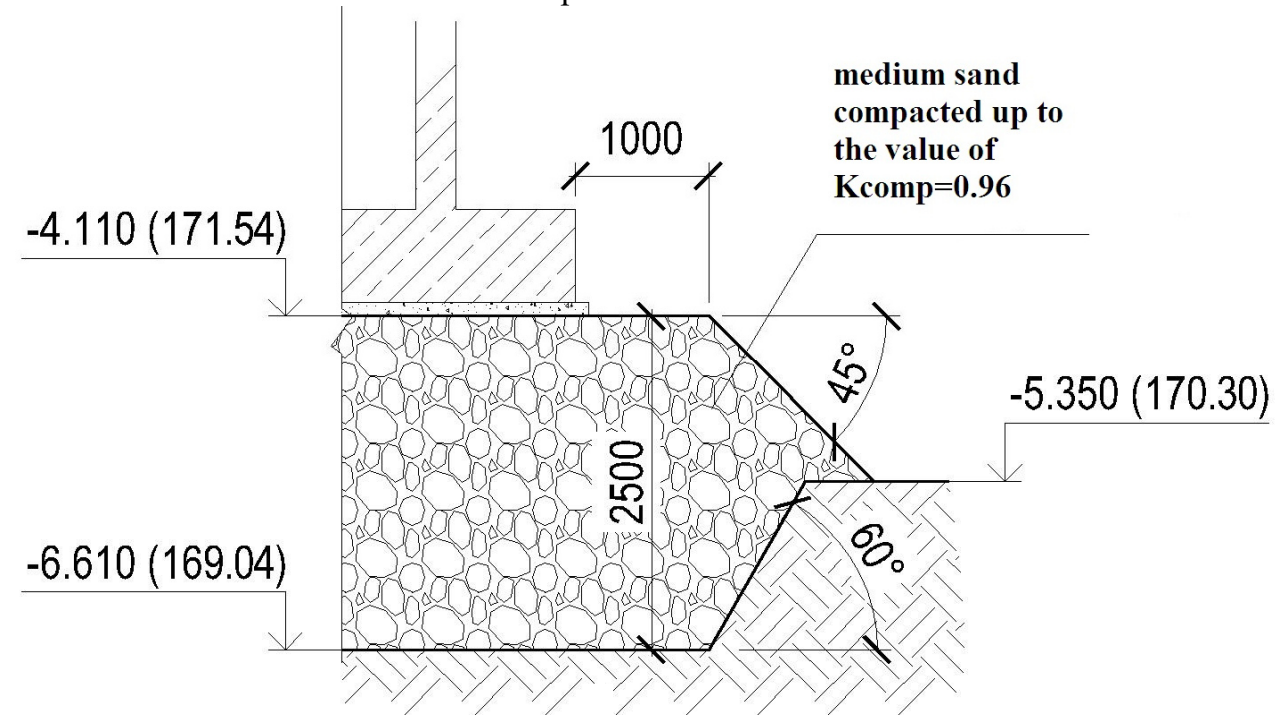

Fig.1. Lay-out of the foundation of the building considered in this article; the sand beds under the foundation plate replace the soft grounds.

The sand beds shouldn't be used if the suffusion is possible [10-12] or the construction site is located in the frost penetration zone with a high level of ground waters, which may cause the flood of sand beds and their following heaving (when freezing).

The grout injection method includes the use of the energy of high-pressure cement mortar streams with air jets, which destroy the soil and mix it with the cement mortar. After the mixture hardening, we obtain a soil-and-cement mass. This method may be used in case of non-stable, water-saturated or damaged soils.

At the stage of design works at the secondary school project in Putilkovo, Moscow Region, the decision had been taken to use the grout injection method. At the lower terrain places with soft grounds under the foundation plates, an artificial soil layer (1 to $2.5 \mathrm{~m}$ thick) was performed with the soil replacement at the depth of 0.8 to $1 \mathrm{~m}$. First, a sand-andgravel mixture with a layer-by-layer compaction was assumed as the material for this artificial soil layer. But later this mixture was changed by a sand mixture with a layer-bylayer compaction $\left(\mathrm{K}_{\mathrm{comp}}=0.96\right)$. So the soil replacement was performed with the use of a sand mixture with a layer-by-layer compaction (thickness of the sand mixture layer was 1 to $2.5 \mathrm{~m}$ ) (Fig.2). 


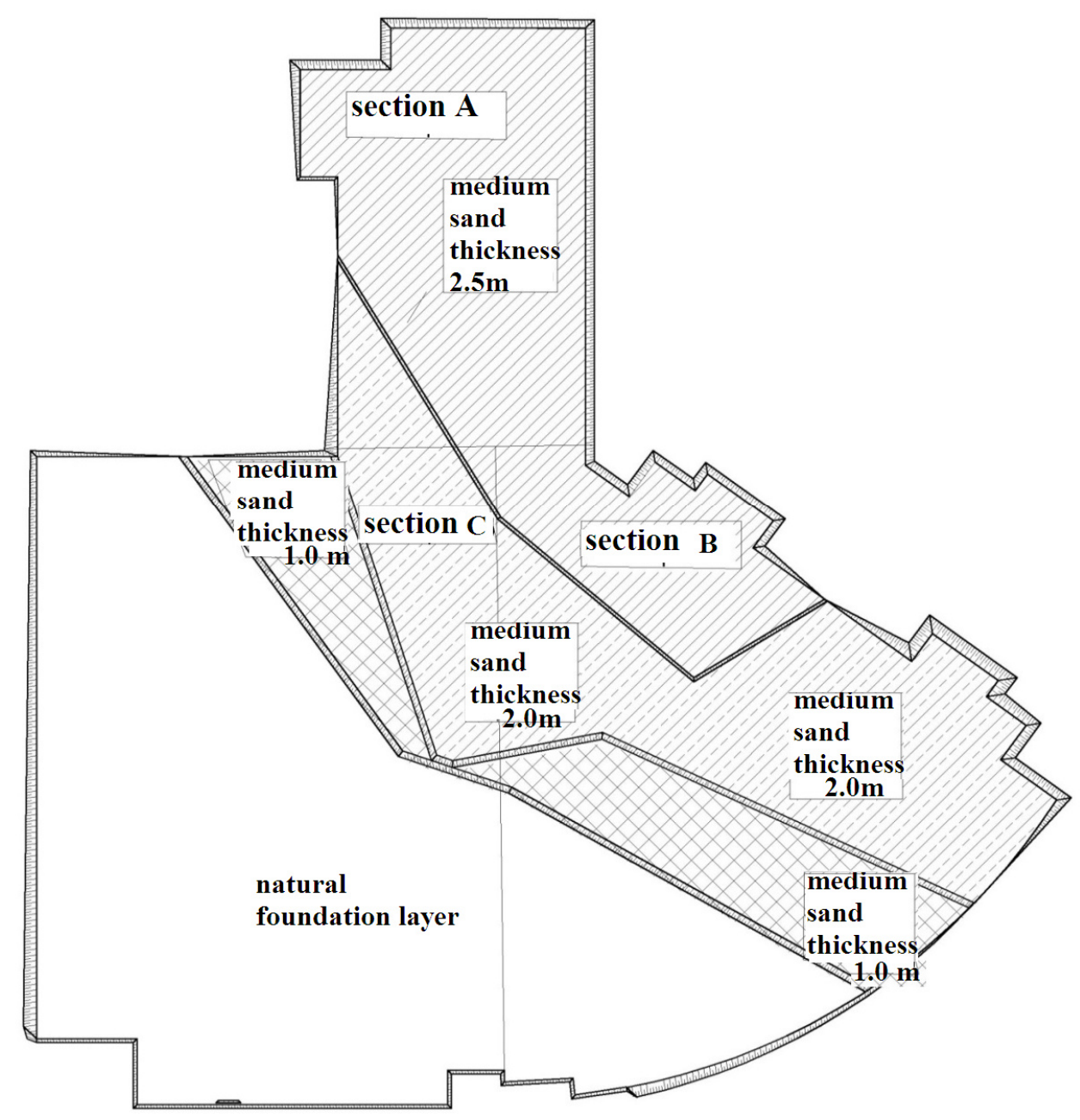

Fig.2. Distribution of sand in the foundation pit.

Before grouting, they noticed a slight settling (not more than $60 \mathrm{~mm}$ ) of the soil layer at the section B. In this connection, the foundation plate was made thicker, so that the plate top was in its design position. After grouting, they noticed some differences (not more than $60 \mathrm{~mm}$ ) along the plate, but first they considered them to be the grouting errors. A fortnight later, they noticed a sharp settling of the plate and the formation of a gap between the foundation plate and the soil. Then they decided to stop the concrete monolith works at the site and to organize a regular supervision of the plate settling. They installed a supervision station along the plate edge (Fig.3). 


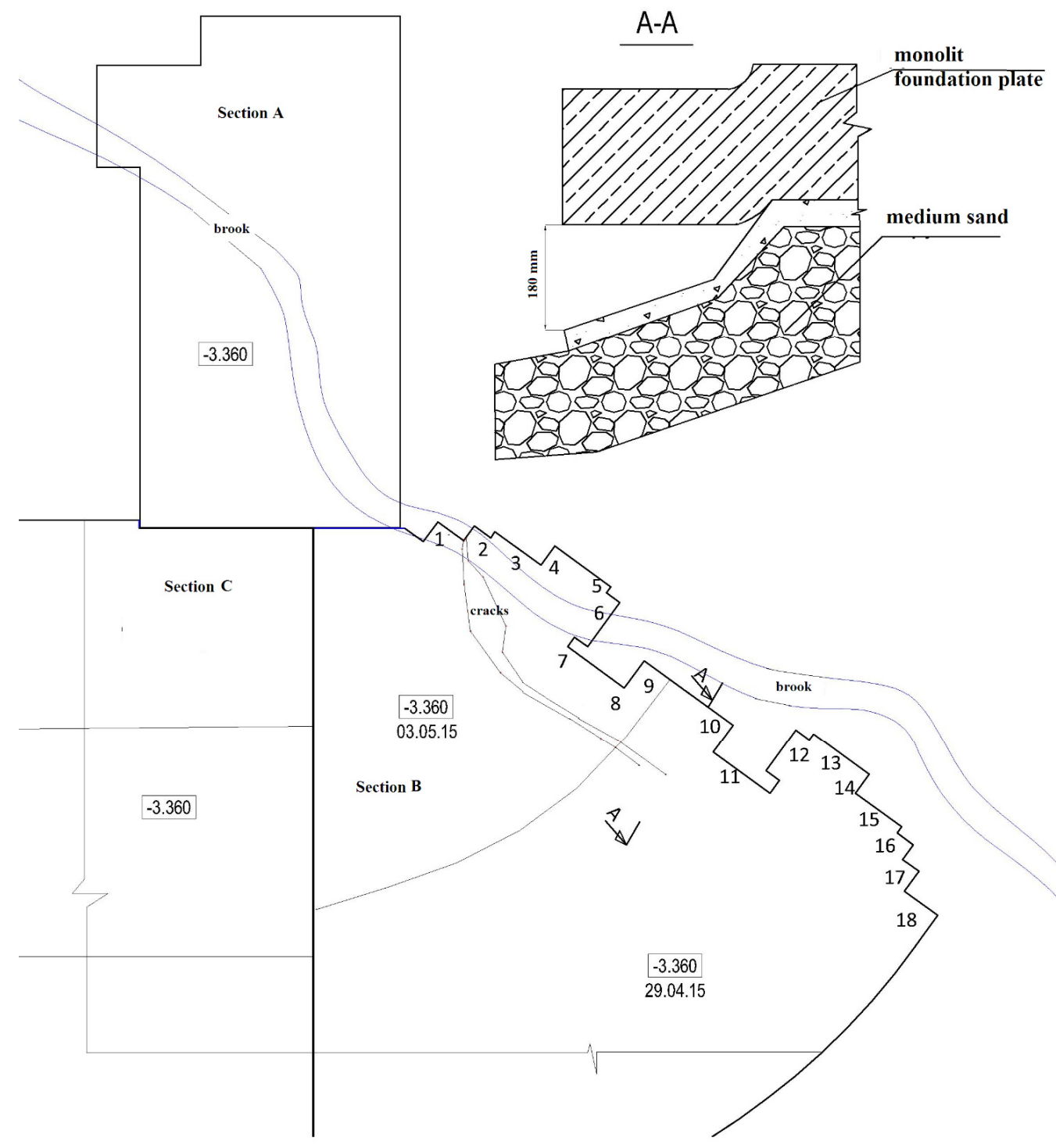

Fig.3. Lay-out of the supervision station.

At first, they controlled the plate every day. Later, when the plate settling became slower, they controlled the plate once or twice a week. They also measured the gap between the foundation plate and the artificial soil layer under the plate and calculated the soil settling (Table 1). 
Table 1. Register of foundation plate settlings for 13.05.2015.

\begin{tabular}{|c|c|c|c|c|c|c|c|}
\hline $\begin{array}{l}\text { Mark } \\
\text { number }\end{array}$ & $\begin{array}{c}\text { Foundatio } \\
\mathrm{n} \text { plate } \\
\text { measuring } \\
\text { mark after } \\
\text { grouting } \\
(29.04- \\
03.05)\end{array}$ & $\begin{array}{c}\text { Plate } \\
\text { measurin } \\
\mathrm{g} \text { mark } \\
\text { for } \\
12.05 .15\end{array}$ & $\begin{array}{c}\text { Plate } \\
\text { measurin } \\
\mathrm{g} \text { mark } \\
\text { for } \\
13.05 .15\end{array}$ & $\begin{array}{l}\text { Plate } \\
\text { settlin } \\
\text { g } \\
\text { during } \\
\text { the } \\
\text { last } \\
\text { day- } \\
\text { long } \\
\text { period, } \\
\text { mm }\end{array}$ & $\begin{array}{l}\text { Plate } \\
\text { settling } \\
\text { within } \\
\text { the } \\
\text { period } \\
\text { from } \\
29.04 \text { till } \\
13.05 .15 \\
\text {, mm }\end{array}$ & $\begin{array}{l}\text { Settling } \\
\text { of the soil } \\
\text { layer } \\
\text { under the } \\
\text { foundatio } \\
\text { n plate } \\
\text { during the } \\
\text { last day- } \\
\text { long } \\
\text { period, } \\
\text { mm }\end{array}$ & $\begin{array}{c}\text { Distance } \\
\text { between } \\
\text { the } \\
\text { artificial } \\
\text { soil layer } \\
\text { top and } \\
\text { the } \\
\text { foundatio } \\
\mathrm{n} \text { plate } \\
\text { bottom, } \\
\mathrm{mm}\end{array}$ \\
\hline 1 & 172,28 & 172,273 & 172,268 & 5 & 12 & 6 & 0 \\
\hline 2 & 172,26 & 172,237 & 172,229 & 8 & 31 & 13 & 0 \\
\hline 3 & 172,24 & 172,204 & 172,197 & 7 & 43 & 13 & 30 \\
\hline 4 & 172,244 & 172,108 & 172,102 & 6 & 142 & & 5 \\
\hline 5 & 172,251 & 172,127 & 172,118 & 9 & 133 & & 0 \\
\hline 6 & 172,245 & 172,162 & 172,153 & 9 & 92 & 15 & 25 \\
\hline 7 & 172,238 & 172,179 & 172,172 & 7 & 66 & 11 & 5 \\
\hline 8 & 172,277 & 172,207 & 172,199 & 8 & 78 & & 10 \\
\hline 9 & 172,244 & 172,198 & 172,194 & 4 & 50 & 11 & 25 \\
\hline 10 & 172,266 & 172,221 & 172,214 & 7 & 52 & 16 & 75 \\
\hline 11 & 172,253 & 172,231 & 172,224 & 7 & 29 & 9 & 20 \\
\hline 12 & 172,224 & 172,135 & 172,127 & 8 & 97 & & 3 \\
\hline 13 & 172,224 & 172,12 & 172,12 & 0 & 104 & 9 & 15 \\
\hline 14 & 172,226 & 172,152 & 172,144 & 8 & 82 & 16 & 10 \\
\hline 15 & 172,225 & 172,151 & 172,144 & 7 & 81 & & 25 \\
\hline 16 & 172,225 & 172,121 & 172,115 & 6 & 110 & & 70 \\
\hline 17 & 172,225 & 172,084 & 172,074 & 10 & 151 & 19 & 70 \\
\hline 18 & 172,225 & 172,186 & 172,183 & 3 & 42 & 12 & 3 \\
\hline
\end{tabular}

After a month from the grouting moment, the foundation plate stopped settling. They controlled the plate for one more month and revealed that the soil layer settled $1 \mathrm{~cm}$ more at the marks 16 and 17. At that moment, the construction site was already water-saturated. The maximum plate settling was equal to $171 \mathrm{~mm}$, the maximum artificial soil layer settling was equal to $330 \mathrm{~mm}$, but, if we take into consideration the fact that the soil layer settling started before the grouting of the foundation, then the maximum soil layer settling was more than $450 \mathrm{~mm}$. 
Table 2. Register of foundation plate settlings for 09.06.2015.

\begin{tabular}{|c|c|c|c|c|c|c|c|c|}
\hline $\begin{array}{c}\text { Mar } \\
\mathrm{k} \\
\text { num } \\
\text { ber }\end{array}$ & $\begin{array}{c}\text { Founda } \\
\text { tion } \\
\text { plate } \\
\text { measur } \\
\text { ing } \\
\text { mark } \\
\text { after } \\
\text { groutin } \\
\text { g } \\
(29.04- \\
03.05)\end{array}$ & $\begin{array}{c}\text { Plate } \\
\text { measuri } \\
\text { ng mark } \\
\text { for } \\
04.06 .1 \\
5\end{array}$ & $\begin{array}{c}\text { Plate } \\
\text { measuri } \\
\text { ng mark } \\
\text { for } \\
09.06 .1 \\
5\end{array}$ & $\begin{array}{c}\text { Plate } \\
\text { settlin } \\
\mathrm{g} \\
\text { within } \\
\text { the } \\
\text { period } \\
\text { from } \\
04.06 \\
\text { till } \\
09.06 . \\
15, \\
\mathrm{~mm}\end{array}$ & $\begin{array}{l}\text { Plate } \\
\text { settling } \\
\text { for the } \\
\text { whole } \\
\text { period, } \\
\text { mm }\end{array}$ & $\begin{array}{l}\text { Plate } \\
\text { settling } \\
\text { within } \\
\text { the } \\
\text { period } \\
\text { from } \\
12.05 \\
\text { till } \\
09.06 .15 \\
\text {, mm }\end{array}$ & $\begin{array}{l}\text { Settling } \\
\text { of the } \\
\text { artificial } \\
\text { soil } \\
\text { layer } \\
\text { under } \\
\text { the } \\
\text { foundati } \\
\text { on plate } \\
\text { for the } \\
\text { whole } \\
\text { period, } \\
\text { mm }\end{array}$ & $\begin{array}{c}\text { Distance } \\
\text { between the } \\
\text { artificial soil } \\
\text { layer top and } \\
\text { the } \\
\text { foundation } \\
\text { plate bottom, } \\
\mathrm{mm}\end{array}$ \\
\hline 1 & 172,28 & 172,261 & 172,262 & -1 & 18 & 11 & 18 & \\
\hline 2 & 172,26 & 172,215 & 172,216 & -1 & 44 & 21 & 44 & \\
\hline 3 & 172,24 & 172,178 & 172,179 & -1 & 61 & 25 & 136 & 75 \\
\hline 4 & $\begin{array}{c}172,24 \\
4\end{array}$ & 172,072 & 172,073 & -1 & 171 & 35 & 231 & 50 \\
\hline 5 & $\begin{array}{c}172,25 \\
1\end{array}$ & 172,082 & 172,082 & 0 & 169 & 45 & 269 & 100 \\
\hline 6 & $\begin{array}{c}172,24 \\
5\end{array}$ & 172,124 & 172,124 & 0 & 121 & 38 & 221 & 100 \\
\hline 7 & $\begin{array}{c}172,23 \\
8\end{array}$ & 172,157 & 172,157 & 0 & 81 & 22 & 139 & 58 \\
\hline 8 & $\begin{array}{c}172,27 \\
7 \\
\end{array}$ & 172,184 & 172,185 & -1 & 92 & 22 & 112 & 20 \\
\hline 9 & $\begin{array}{c}172,24 \\
4 \\
\end{array}$ & 172,171 & 172,173 & -2 & 71 & 25 & 107 & 35 \\
\hline 10 & $\begin{array}{c}172,26 \\
6 \\
\end{array}$ & 172,197 & 172,197 & 0 & 69 & 24 & 189 & 120 \\
\hline 11 & $\begin{array}{c}172,25 \\
3\end{array}$ & 172,211 & 172,212 & -1 & 41 & 19 & 66 & 25 \\
\hline 12 & $\begin{array}{c}172,22 \\
4 \\
\end{array}$ & 172,105 & 172,105 & 0 & 119 & 30 & 144 & 25 \\
\hline 13 & $\begin{array}{c}172,22 \\
4\end{array}$ & 172,084 & 172,084 & 0 & 140 & 36 & 210 & 70 \\
\hline 14 & $\begin{array}{c}172,22 \\
6 \\
\end{array}$ & 172,12 & 172,121 & -1 & 105 & 31 & 175 & 70 \\
\hline 15 & $\begin{array}{c}172,22 \\
5\end{array}$ & 172,128 & 172,13 & -2 & 95 & 21 & 215 & 120 \\
\hline 16 & $\begin{array}{c}172,22 \\
5\end{array}$ & 172,1 & 172,102 & -2 & 123 & 19 & 303 & 180 \\
\hline 17 & $\begin{array}{c}172,22 \\
5\end{array}$ & 172,065 & 172,065 & 0 & 160 & 19 & 330 & 170 \\
\hline 18 & $\begin{array}{c}172,22 \\
5\end{array}$ & 172,179 & 172,179 & 0 & 46 & 7 & - & - \\
\hline
\end{tabular}

Later the site engineers realized that such a sharp artificial soil layer settling was caused by the presence of water. As it has turned out, a brook ran through the construction site (Fig.3). Before the construction works, the brook was partly taken into the casing outside the foundation pit, and the soil replacement in the vicinity of the brook bed was stipulated. But before the construction works, the ravine with the brook was filled up with the soil, and 
the brook wasn't revealed until the spring floods. The excavation works started with the section A in February-March, 2015, and the brook wasn't discovered in the construction site zone by that time. So, the section A of the foundation plate was cast by the end of March, 2015. Then the section $\mathrm{C}$ of the foundation plate was cast, and only then the works with the section B started. Probably then the spring floods started, and the brook delivered much water, so the sand from under the foundation plate was washed out.

The construction works at the sections A and B continued only after the following procedures:

1) The foundation soil stabilization was performed with the use of soil-and-cement columns in accordance with SP 24.13330.2011 "Piles foundations. Actual edition of SNiP 2.02.03-85". They used 467 columns with the diameter of $750 \mathrm{~mm}$ and the length of $7 \mathrm{~m}$ from the bottom mark of the foundation plate (Fig.4). The soil-and-cement columns were performed by the grout injection method through the wells (diameter: $112 \mathrm{~mm}$ ) drilled in the foundation plate body.

2) In the basement parts at the sections $A$ and $B$, the additional vertical bearing structures were erected, and the floor over the basement was strengthened by additional reinforcement rods.

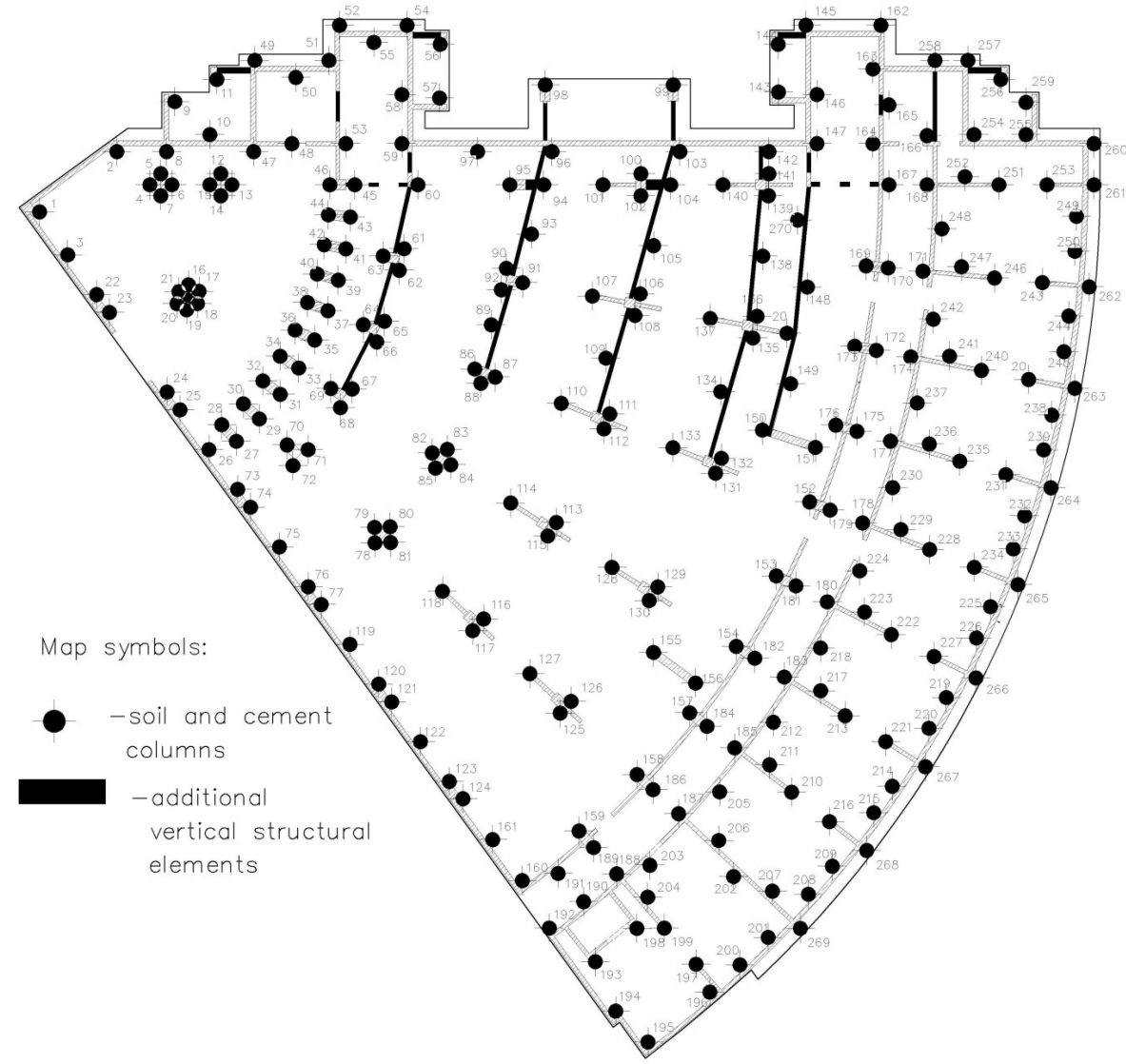

Fig. 4. Lay-out of soil-and-cement columns and additional vertical structural elements at the section B. 


\section{Conclusions}

The underestimation of hydro-geological conditions at the design stage of the project led to incorrect design solutions. The chosen method of soil replacement under the building foundation plates turned out to be inefficient and led to the foundation deformations. As a result of spring floods, the artificial soil layers from under the foundation plates were washed out. The soil-and-cement columns were arranged timely; they allowed to strengthen the artificial soil layers under the foundation plates and to avoid possible negative aftereffects concerning non-uniform building settlings. The construction outage, the development of new design solutions, the introduction of these solutions led to the increase in both the construction cost and the construction period, which could be avoided with a proper estimation of hydro-geological conditions at the construction site.

\section{References}

1. E.Z. Kuchukov, T.V. Zommer, N.A. Filkin, S.A. Laukhin, Necessary geological-andengineering surveying works as the engineering support of construction. Scie. Revue, No.6, pp. 189-193 (2016)

2. E.Z. Kuchukov, T.V. Zommer, N.A. Filkin, About the necessity of monitoring of geological-and-engineering surveying works in construction for the purpose of prevention of destruction of structures. Scie. Revue, No. 3 (2016)

3. A.N. Yulin, Geological-and-engineering aspects of geo-engineering supervision in the process of erection of artificial sand foundations. Eng. Surv. Works, No.10, pp. 28-32 (2010)

4. I.A. Potapov, A.D. Potapov, A.A. Shimenkova, Geo-ecological estimation of the strength formation for sandy soils (in the context of physical-and-chemical theory of effective stresses). MGSU Proceedings. No. 2., pp.166-180 (2013)

5. F.Z. Nguen, Study of the dependence of strength characteristics of the soil on its physical state. Civ. eng. j., No. 9, pp.23-28 (2012)

6. V.M. Bezruk, Theoretical principles of the soil strengthening with the cements. Moscow, Avtostroyizdat (1956)

7. I.I. Broid, Injection technologies. Moscow, AVS Publishing House (2004)

8. A.G. Malinin, Grouting of soils: monograph. Perm: Presttime (2007)

9. A.V. Chernyakov, Grouting of soils in urban construction//Science and technology in the field of road construction. No. 3, pp. 10-14 (2011)

10. I.A. Lavrussevich, V.P. Khomenko, A.A. Lavrussevich, Underestimation of suffusion danger in the process of erection of plate concrete structures. Indust. and civil const.., No.11, pp. 21-24 (2015)

11. A.A. Lavrussevich, V.P. Khomenko, Engineering protection of territories affected by the loess pseudo-karst. MGSU Proceedings. No. 10, pp. 213-220 (2012)

12. I. Rubtsov, R. Alisultanov, A. Zinatullin, N. Midrigan, Detection of fatigue damage in long-span reinforced concrete structures. MATEC Web of Conf., 27, "27th R-S-P Seminar, Theoret. Found. of Civil Eng. (27RSP), TFoCE 2018", p. 03010 (2018) 